\title{
SweetSpot - a computer system for storing and sharing data on the rock properties of shale formations
}

The paper presents a computer system used for the storage and processing of information regarding the rock properties of shale formations, designed collectively by the Oil and Gas Institute - National Research Institute and the Warsaw University of Technology. The structure of this system is adapted for collecting and systematising the available measurement data on shale formations in including the geochemical, petrophysical, geomechanical, petrographic, geophysical and stratigraphic data, as well as chemical and X-ray analyses and drill core photographs, along with their comparative and statistical analyses. This system, called "SweetSpot", uses client-server architecture. The data are stored on the server, and are made available to users by the web browser that communicate with the server by the Internet. The end user is not charged with any additional costs or investment expenditures when using the base - all that is necessary is a computer with standard software for accessing WWW pages. The system is designed to be flexible, which means easy extensions with additional types of measurements. It will be successively upgraded with new functionalities. This particularly involves the use of statistical methods for seeking similarities between separate shale structures.

Key words: shale gas, shale properties, database, drill core, core photographs.

\section{SweetSpot - system komputerowy do przechowywania i udostępniania danych o właściwościach skał formacji łupkowych}

W artykule omówiono, opracowany wspólnie przez Instytut Nafty i Gazu - Państwowy Instytut Badawczy i Politechnikę Warszawską, komputerowy system gromadzenia i przetwarzania informacji dotyczących właściwości skał formacji łupkowych. Budowa tego systemu jest próbą zebrania i usystematyzowania dostępnych danych pomiarowych dotyczących formacji łupkowych w tak szerokim zakresie (dane geochemiczne, petrofizyczne, geomechaniczne, petrograficzne, geofizyczne, startygraficzne, analizy chemiczne i rentgenowskie, zdjęcia rdzeni wiertniczych), ich analizy porównawczej oraz statystycznej. System ten, nazwany SweetSpot, wykorzystuje architekturę klient-serwer. Dane są przechowywane na komputerze centralnym nazywanym serwerem i są udostępniane użytkownikom za pomocą sieci Internet. Taka forma komunikacji zapewnia możliwość efektywnego korzystania ze zgormadzonych wyników badań laboratoryjnych i innych pomiarów we wszystkich miejscach, gdzie istnieje dostęp do Internetu. Użytkownik końcowy nie ponosi żadnych dodatkowych kosztów czy nakładów inwestycyjnych na etapie korzystania z bazy - konieczny jest tylko komputer ze standardowo zainstalowanym oprogramowaniem do obsługi witryn WWW. System zaprojektowany został w taki sposób, aby był elastyczny, co oznacza łatwą rozbudowę o dodatkowe typy pomiarów. Będzie on sukcesywnie rozbudowywany o nowe funkcjonalności. W szczególności dotyczy to zastosowania metod statystycznych w celu poszukiwania podobieństw pomiędzy odrębnymi strukturami łupkowymi.

Słowa kluczowe: gaz z formacji łupkowych, właściwości łupków, baza danych, rdzeń wiertniczy, zdjęcia rdzenia. 


\section{Introduction}

The extraction of gas from shale formations on an industrial scale requires drilling a large number of wells, which must form an adequately "dense" grid enabling the extraction of gas in economically profitable amounts. This also allows collecting a large amount of rock material in the form of drill cores, which can be used to conduct a wide range of examinations intended to precisely determine the properties of the penetrated shales. This usually requires the creation of large amounts of data involving such fields as geology, petrophysics, geochemistry, geomechanics, reservoir engineering, geophysics, etc. These data are obtained from lab measurements and those performed directly in the wells and acquired as a result of various kinds of analyses and interpretations. On this basis it is possible to select a suitable reservoir completion system and to use a proper gas extraction system.

The acquired data have, in a definite majority of the cases, one common feature - they are available in a digital form, saved on computer hard drives, CD/DVDs or other memory devices. Their use for seeking specific information, is relatively easy, if all the data on the given well are gathered in one place. Unfortunately, this is seldom the case - these materials are dispersed in the archives of various departments or branches of companies, and access to them may depend on the level of authorisation assigned to employees, etc. The situation is even worse in the case of archival data, stored in a "standard" manner on paper. Once they are located, the materials in digital form may be quickly sent, for instance via the internet, while the "paper" form of documentation requires additional actions (copying, scanning, etc.). It can therefore be concluded that the use of laboratory examination results and other information about the well may be a very time-consuming activity, and therefore a costly one.

Additional costs are necessary if we have to use the drill cores. They are usually stored in core repositories, sometimes located at a considerable distance from the company headquarters. In this case, the use, in any way, of the core material stored in the repositories is a time-consuming activity, requiring visit to such a core repository. Additionally, such a visit may prove to be absolutely unnecessary when, for example, due to the time which has passed, the core has disintegrated or unavailable. Therefore, the original appearance of this core will not be known, nor will it be possible to obtain any interesting information (for instance on sedimentology).

This problem may be solved by taking photographs of drill cores, preferably as soon as possible after acquiring them from the borehole, and before the collection of samples for laboratory analyses, which will allow, primarily, the preservation of the original appearance of these cores. The portable unit for digital photography of drill cores, owned by the Oil and Gas Institute - National Research Institute, may be helpful in this regard, making it possible to obtain images of the complete core or any continuous drill core intervals as digital photographs.

Core photographs may be used in sedimentology, in planning and developing work for the wells, etc. Such images may be an element of the calibration of various geophysical curves, combined with, for instance, direct gamma measurements performed in laboratory conditions on a drill core collected from the borehole. The analysis of drill core photographs may also provide additional information which cannot be interpreted or cannot be seen in geophysical logging charts, due to the resolution of geophysical probes being too low. Having at one's disposal the picture material integrated with other data allows savings in financial resources, since it is possible to obtain information on drill cores without the necessity to visit a core repository.

In order to enable quick and efficient use of photographs and other data regarding the boreholes, they can be gathered in one place, for instance in a database. For this reason, as part of the execution of the first stage of the BlueGas project, the Oil and Gas Institute - National Research Institute, along with the Warsaw University of Technology have begun to compile a computer system for the collection and processing of information regarding shale formations. This system, hereinafter referred to as SweetSpot, uses client-server architecture. The data are stored on a central computer called the server, and are send to users using Internet. This form of communication provides the ability to efficiently use the gathered results of laboratory research and other measurements in all places where there is internet access, for example away from the company headquarters. In this solution the end user is not charged with any additional costs or investment expenditures when using the base - all that is necessary is a computer with standard software for accessing WWW pages.

According to the authors' knowledge, this is Poland's first attempt to compile and systematise the available measurement data on shale formations in such a wide range (geochemical, petrophysical, geomechanical, petrographic, geophysical, stratigraphic data, as well as chemical and X-ray analyses and drill core photographs), along with their comparative and statistical analyses.

The system has been designed to be flexible, which means easy extensions with additional types of measurements. Additionally, the system is designed to ensure efficient operation, meaning a user-friendly way of collecting, managing and analysing the information contained therein, along with the possibility of maintenance and the generation of reports. 


\section{Assumptions regarding the database}

The performed conceptual work allowed to define the primary assumptions of the designed shale formation database. These assumptions are listed below:

- storage of lithostratigraphic, mineralogical, petrophysical, geochemical and geomechanical data, along with chemical analyses and other information about cores and examination results,

- storage of drill core photographs and other graphical images,

- data stored in the central database,

- access to the data is possible for authorised users (development of an access authorisation mechanism),

- the ability to enter new data, along with their import, export and editing by authorised users,

- it is possible to browse and use the data in a manner typical for standard internet browsers for WWW pages,

- ensuring adequate performance of the system (enabling, e.g. problem-free and quick browsing and loading of .jpg format images).

Such assumptions are satisfied using the systems with three-layer architecture, with a separate data storage layer, a data processing layer and a presentation layer. It was decided to use the architecture of an internet application, presented schematically in Figure 1, where the data storage layer and most algorithms are provided by the central server, while the presentation layer and the algorithms testing the correctness of the input data, as well as the algorithms generating the plots, are placed in the user's computer. The whole system will be efficient if the central server is a computer with adequately high performance. Such a computer may be gradually upgraded with the increasing number of users and the volume of the stored data. The user's computer does not have to be an efficient machine; it just needs to have a WWW browser supporting the currently used network protocols. An additional advantage of the presented solution is the lack of the need to update the software on the user's part, which greatly simplifies the maintenance of the system.

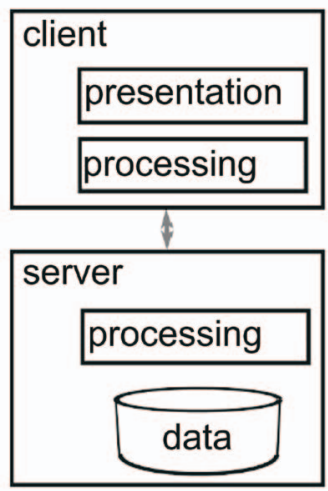

Fig. 1. The three-layer architecture of the SweetSpot

\section{The unit for digital photography of drill cores}

As mentioned above, the drill core photographs constitute a crucial element of the information on the rocks penetrated by the given borehole. The commonly used technique of photographic documentation of drill cores in most cases involves the construction of huge and expensive stationary units (for example by the Core Lab and Terra Scan companies), which in turn necessitates the delivery of the cores to the place where the photographs are to be taken. The photographic process itself usually requires moving the cores from boxes to specialised troughs in the unit, which in the case of poorly cohesive rocks may be troublesome and create problems of a technical nature if no special casings are used to prevent the core from breaking in the process of coring and of removal from the core barrel.

The Oil and Gas Institute - National Research Institute has designed and constructed a portable, automated unit for digital photography of drill cores $[1,2]$. It was created in order to document the core material in the form of digital photographs with recurrent quality parameters and high resolution. Its advantage is the simplicity of operation and the possibility of transportation by car, which makes it possible to take the pictures directly, for example in core repositories or in the Ordering Party's office. The device is adjusted to be installed on typical boxes, designed for the storage of cores and used in the local petroleum industry. This solution, unlike the specialised stationary units, to which the cores need to be delivered, allows reduction of costs of the undertaking, and in the case of poorly cohesive rocks it diminishes the risk of additional damage to the core. The unit (Fig. 2) is provided with a simple control panel used to set the required work parameters.

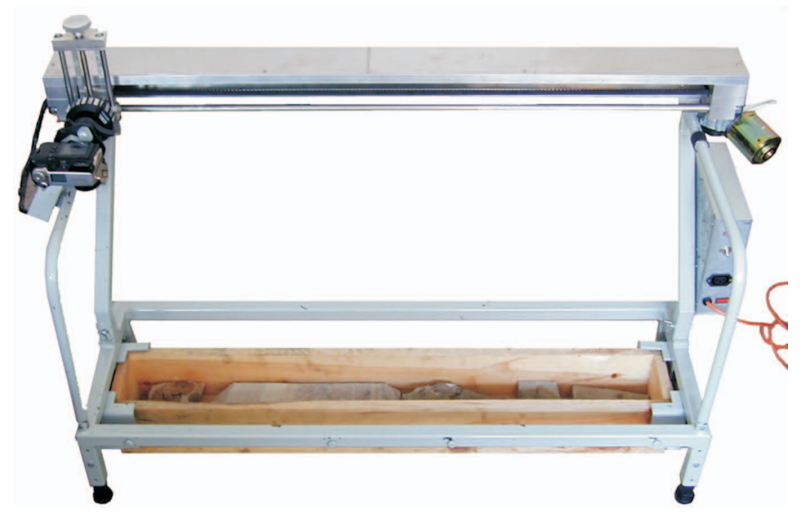

Fig. 2. The portable unit for drill core photography 
The core photography procedure itself is as follows: pictures of one box ( $1 \mathrm{~m}$ of core) are taken upon putting the core boxes on the floor of the core repository. The unit is then moved to the next box, and the whole box with the core inside is once again photographed. These actions are repeated for all boxes.
Once the "photo shoot" is over, the photographs are subjected to digital processing ("merging"), the result of which is a picture of one box with a $1 \mathrm{~m}$ core segment inside. Finally, a 1 metre measure is superimposed over each box. Figures 3 and 4 present sample images of one drill core box upon "assembly", and of the same core with the measure in place.

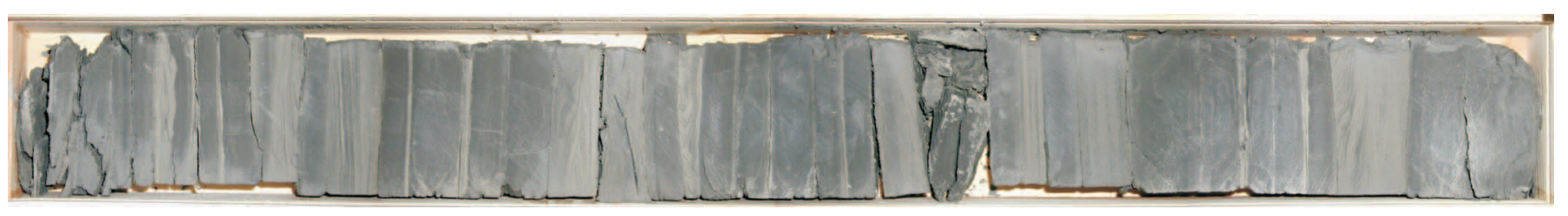

Fig. 3. A picture of the box with the drill core

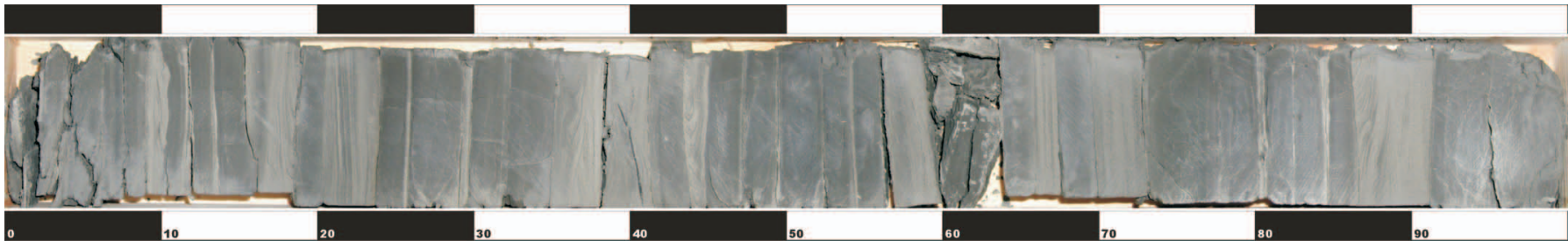

Fig. 4. The core with the measure (length: 1 metre)

\section{The SweetSpot system}

The SweetSpot use: PostgreSQL 9 and Python 2.7 with libraries on server side, and JavaScript with libraries on client side. A chart of the modules is presented in Figure 5. A similar solution is used in software developed in Warsaw University of Technology to store and analyse biological and medical data [5].

The data storage layer, depicted in Fig. 4, allows adding new types of measurements; the values can be additionally grouped into sections. This enables prompt navigation across the available data. The application is provided with simplified mechanisms for authorisation and authentication; only authorised users can access the stored data, and additionally, only some of those users can edit the data; others can only read them.

Currently, the user interface has two language versions (Polish and English), but a mechanism for the creation of other language versions has been provided.

In short, the system's primary functions are:

- the ability to define meanings (measurement data) and to group the meanings into sections,

- displaying the list of boreholes and the location of boreholes on Google maps,

- editing, browsing and managing the data and the examination results entered into the base,

- the ability to import and export the data into/from the base,

- browsing and managing the drill core photographs, scaling of the images, generating collective images,

- generating plots and tables for selected data,
- managing the dictionary data,

- filtering the data.

In accordance with the concept and the developed project, the following results of laboratory analyses and measurements will be entered into the shale formation database $[3,4,6]$ :

- data on the boreholes (name, description, coordinates, location of the boreholes on Google maps),

- photographs of the drill cores,

- petrophysics (bulk density, material density and density of solid particles, total porosity, open porosity, fracture porosity, fracture permeability and absolute permeability, fracture volume index, saturation with reservoir fluids (Dean Stark) in total and open porosity),

- cation-exchange capacity (CEC),

- X-ray analyses (mineral composition (XRD)),

- nuclear magnetic resonance (NMR) (the amount of irreducible water and the water connected to the fractures, total porosity coefficient, coefficient of saturation with irreducible water),

- chemical analyses (the amount of main elements recalculated to oxides, trace elements and rare earth elements),

- geochemistry (pyrolytic Rock-Eval analysis, extractable organic substance (ESO), selected indicators of the distribution of biomarkers of saturated hydrocarbons),

- the impact of the solutions of salt and liquid on the shales (swelling, CST (capillary soaking time), sensitivity index (based on CST), disintegration of the shale), 
- the results of geomechanical examinations (strength tests and ultrasound tests),
- the stratigraphy and lithology of the examined shale samples.

\begin{tabular}{l}
\multicolumn{1}{|c}{ Borehole } \\
id: autoint \\
name: varchar \\
latitude: int \\
longitude: int \\
description: int \\
coordinateX: varchar \\
coordinateY: varchar
\end{tabular}
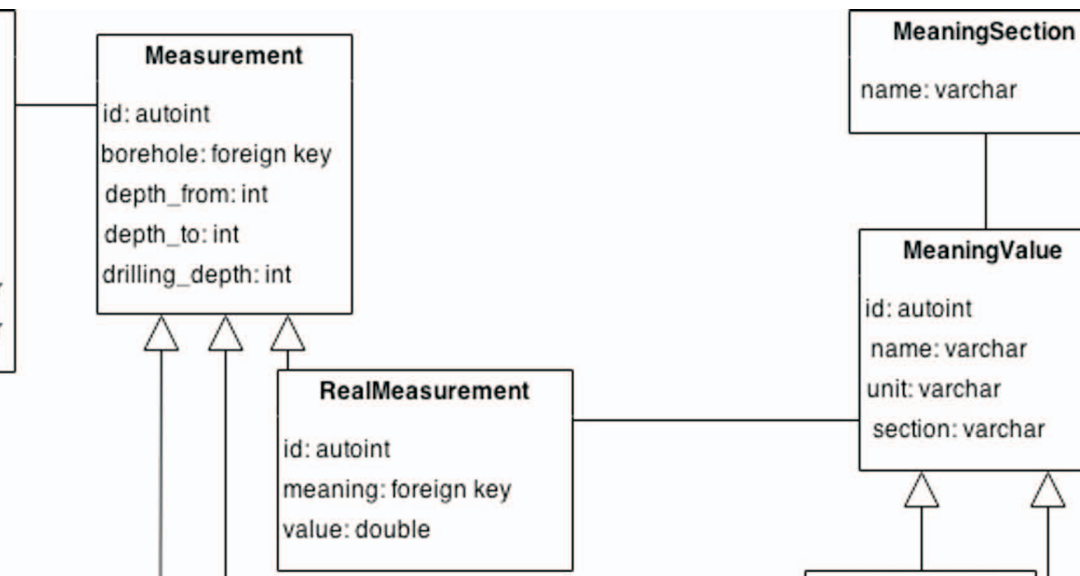

name: varchar
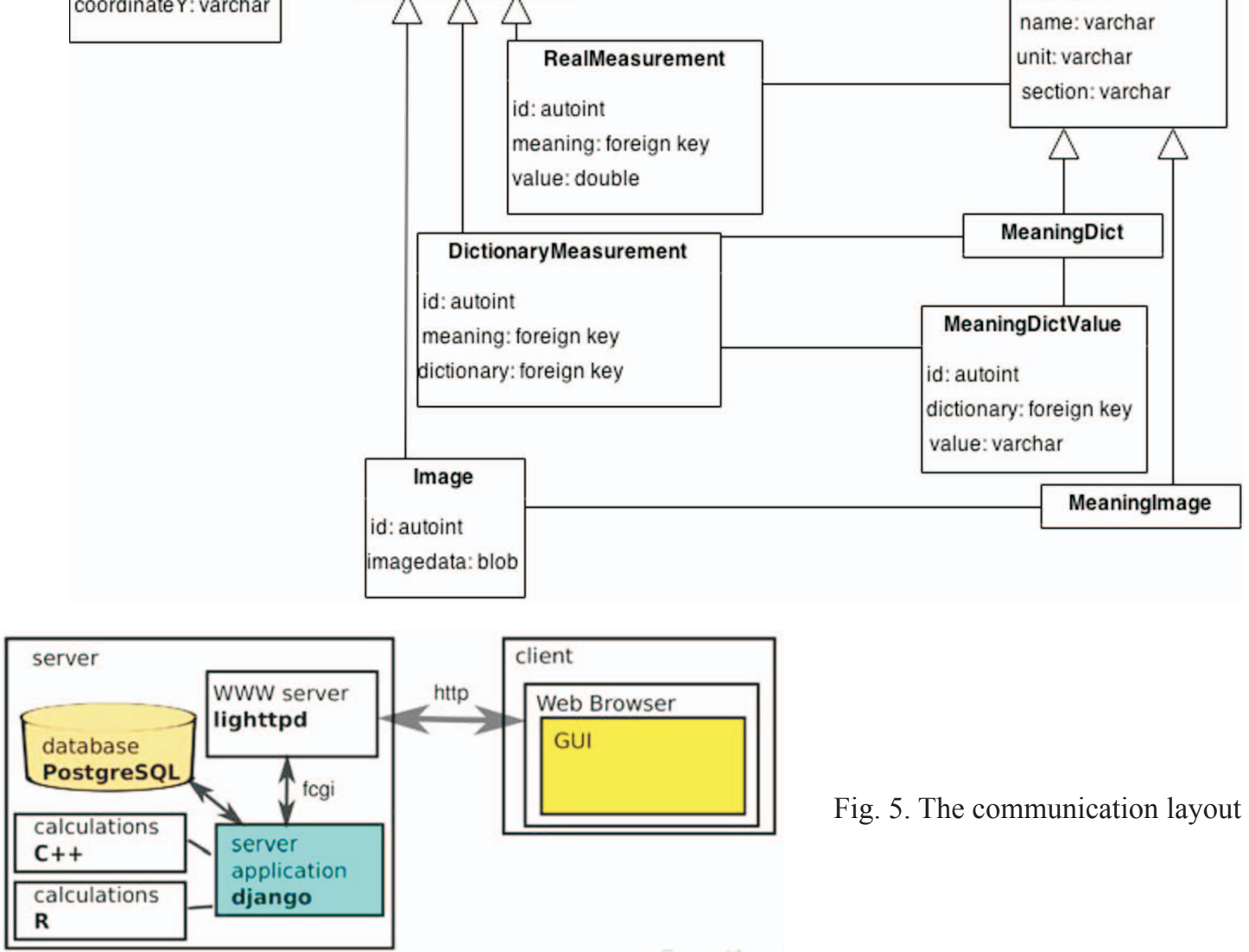

Fig. 5. The communication layout of the base

\section{The user interface}

As stated above, communication with the database is executed by means of the internet, and its use and management are handled via a WWW browser. The user interface has been optimised for Google Chrome, although the application also works properly in the environment of other browsers (Firefox,
Internet Explorer). Sample screenshots of the developed user interface are presented below. A detailed description of the interface (42 pages) constitutes additional material, included in the operating manual. Instruction films are also available, presenting the typical conveniences of the SweetSpot system.

\section{Summary}

As a result of the performed work, a concept and draft have been prepared and a prototype has been constructed for the computer system for the collecting and processing of information on shale formations, taking into account their specific features. A working test application has been installed on a production server in the Oil and Gas Institute - National Research Institute; a demonstration version has also been installed. The system will be gradually extended with new functionalities. This involves in particular the use of statistical methods for seeking similarities between separate shale structures.

Having at one's disposal the borehole documentation in a digital form, including the photographs of drill cores, allows for:

- maintaining the original appearance of the drill cores,

- visual analysis of the core material without the necessity 


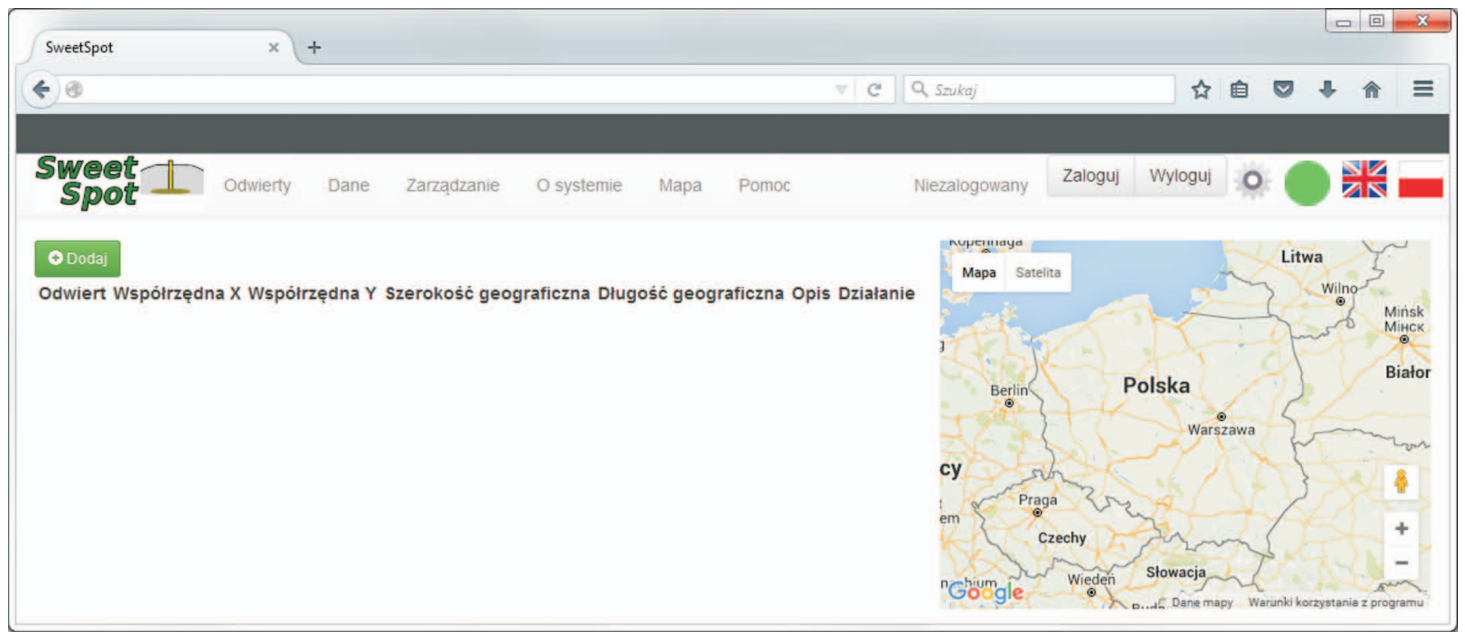

Fig. 6. A view of the home page before logging into the application

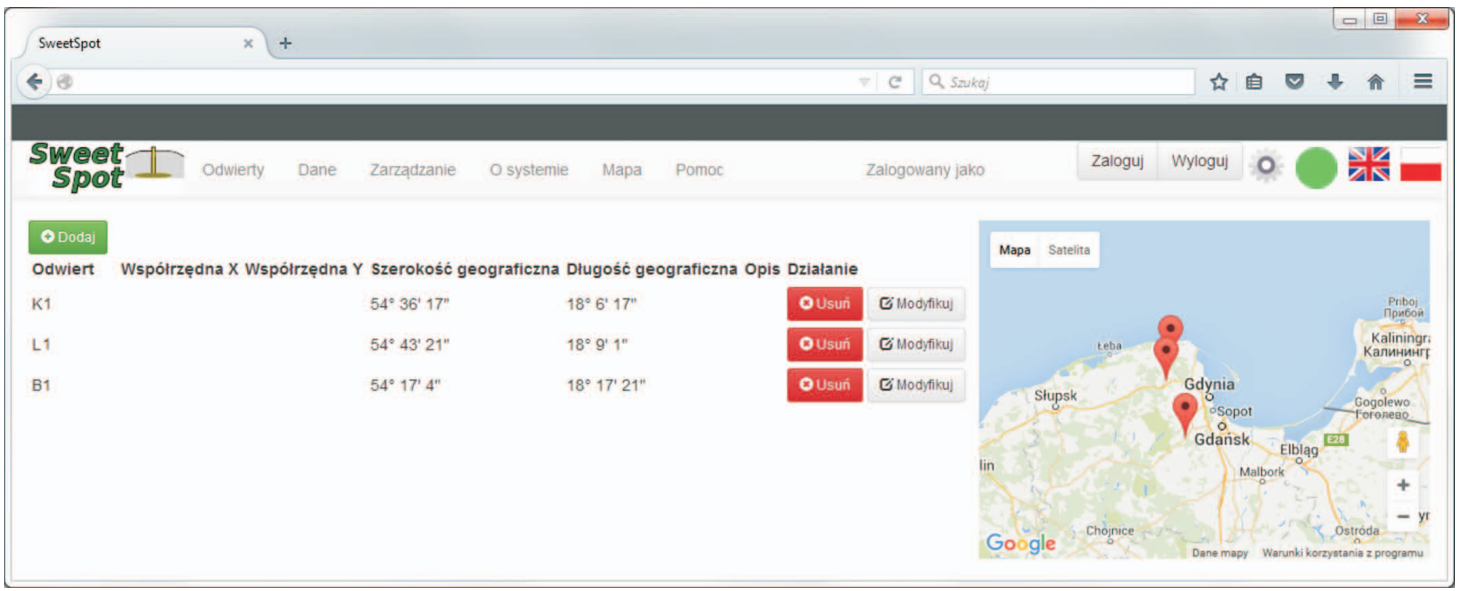

Fig. 7. A view of the home page after logging into the application (visible location of boreholes on Google maps)

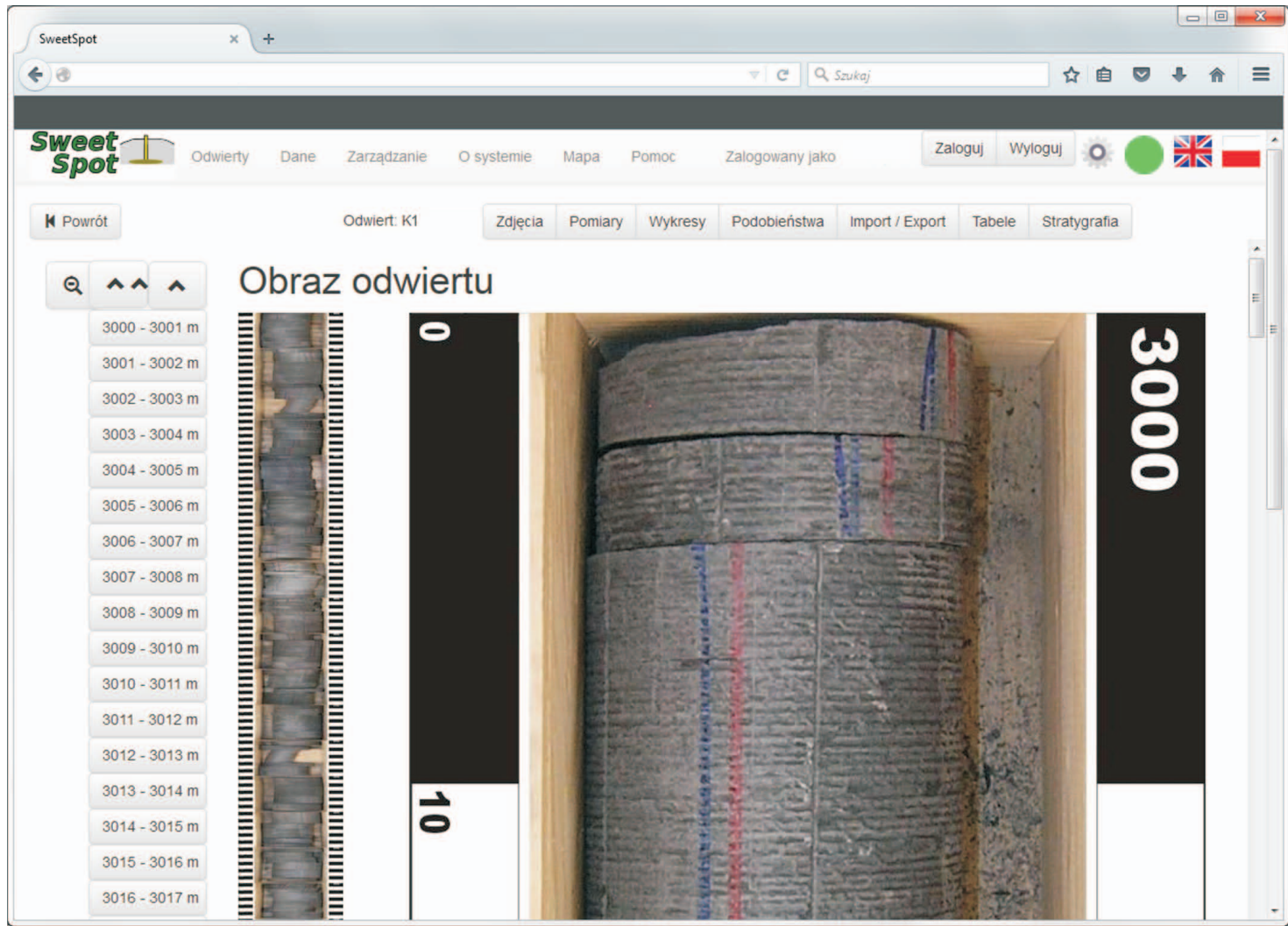

Fig. 8. A page with drill core photographs 


\section{NAFTA-GAZ}

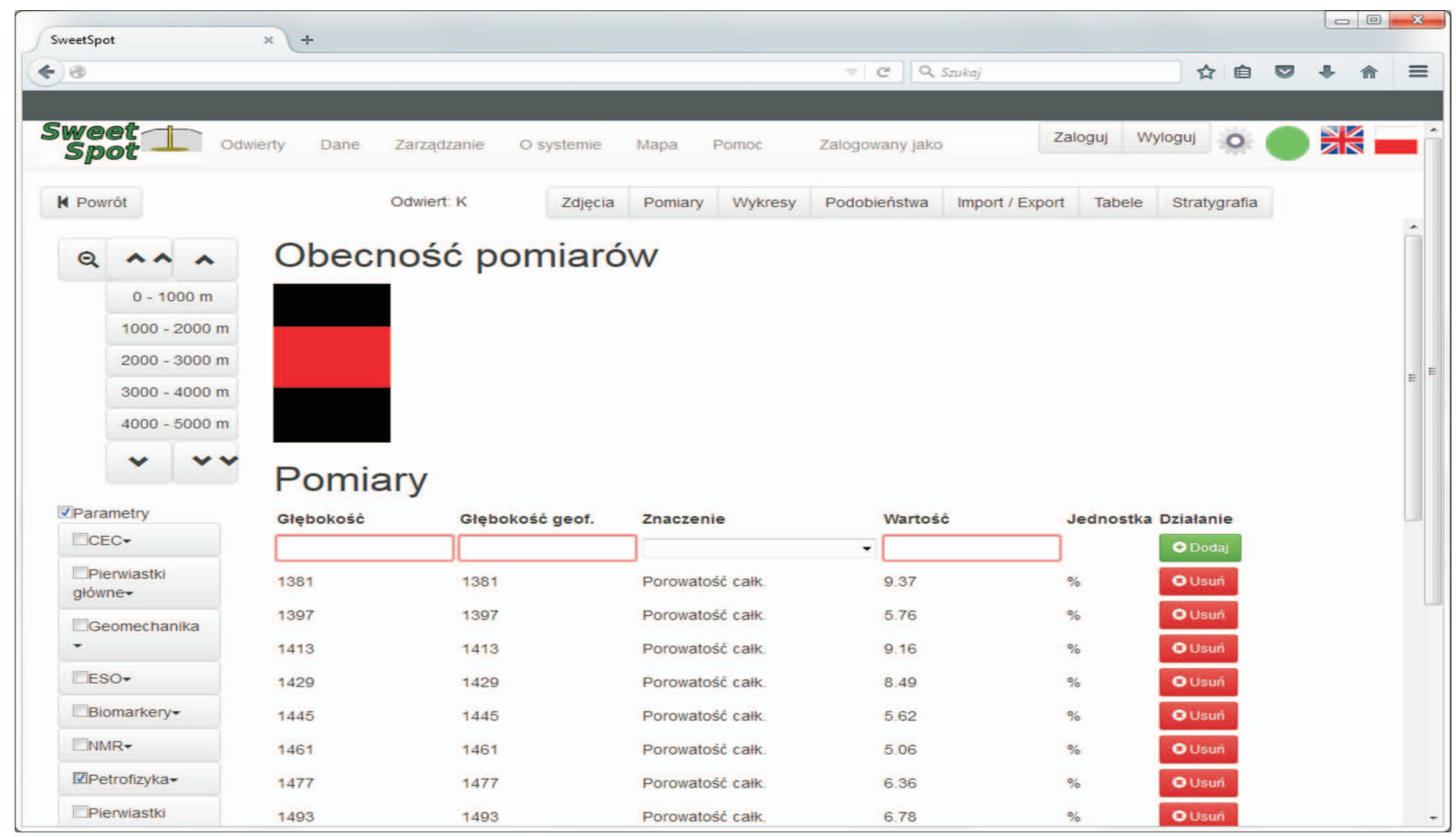

Fig. 9. A page with measurement results entered into the database

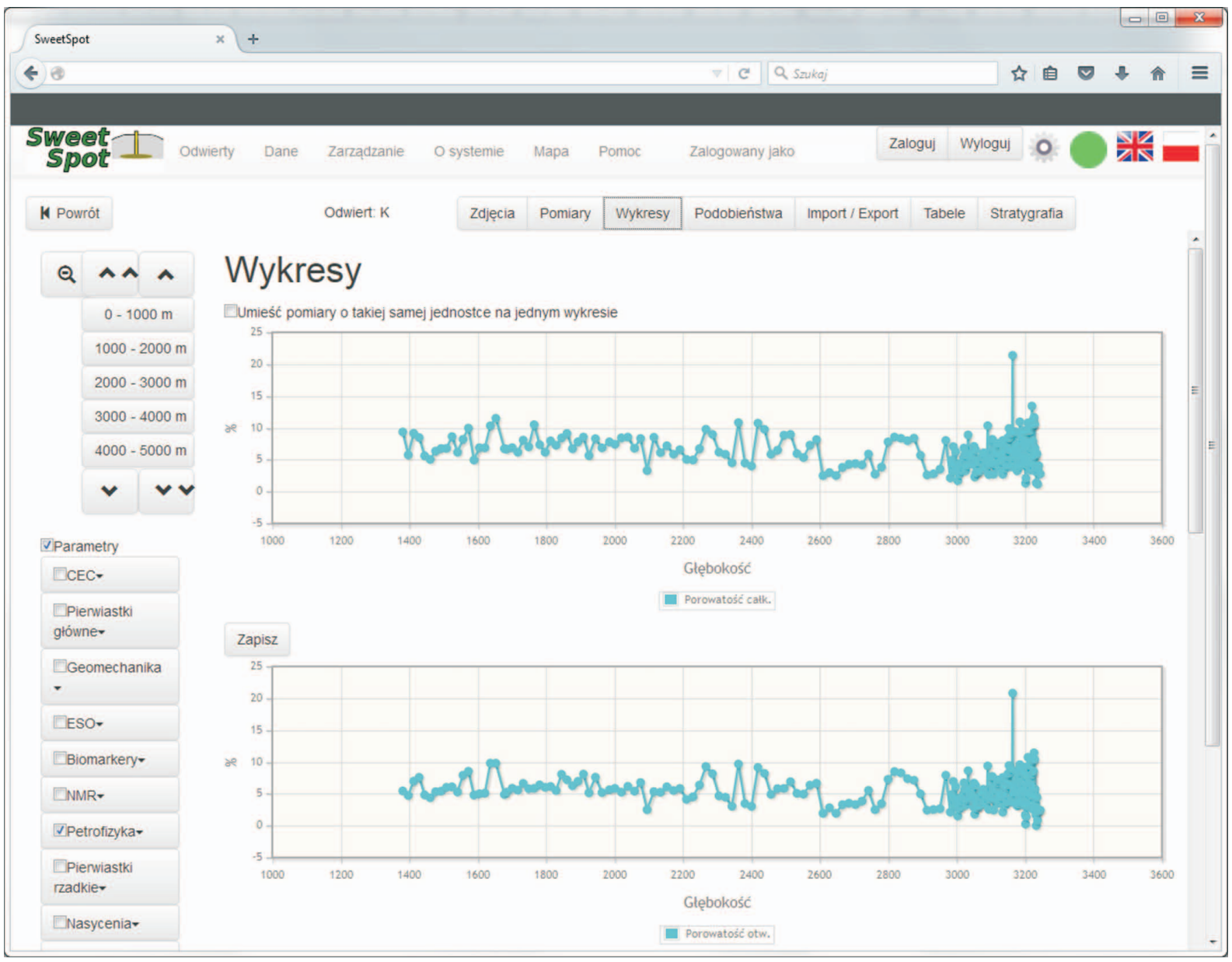

Fig. 10. Sample plots for the "filtered" data 


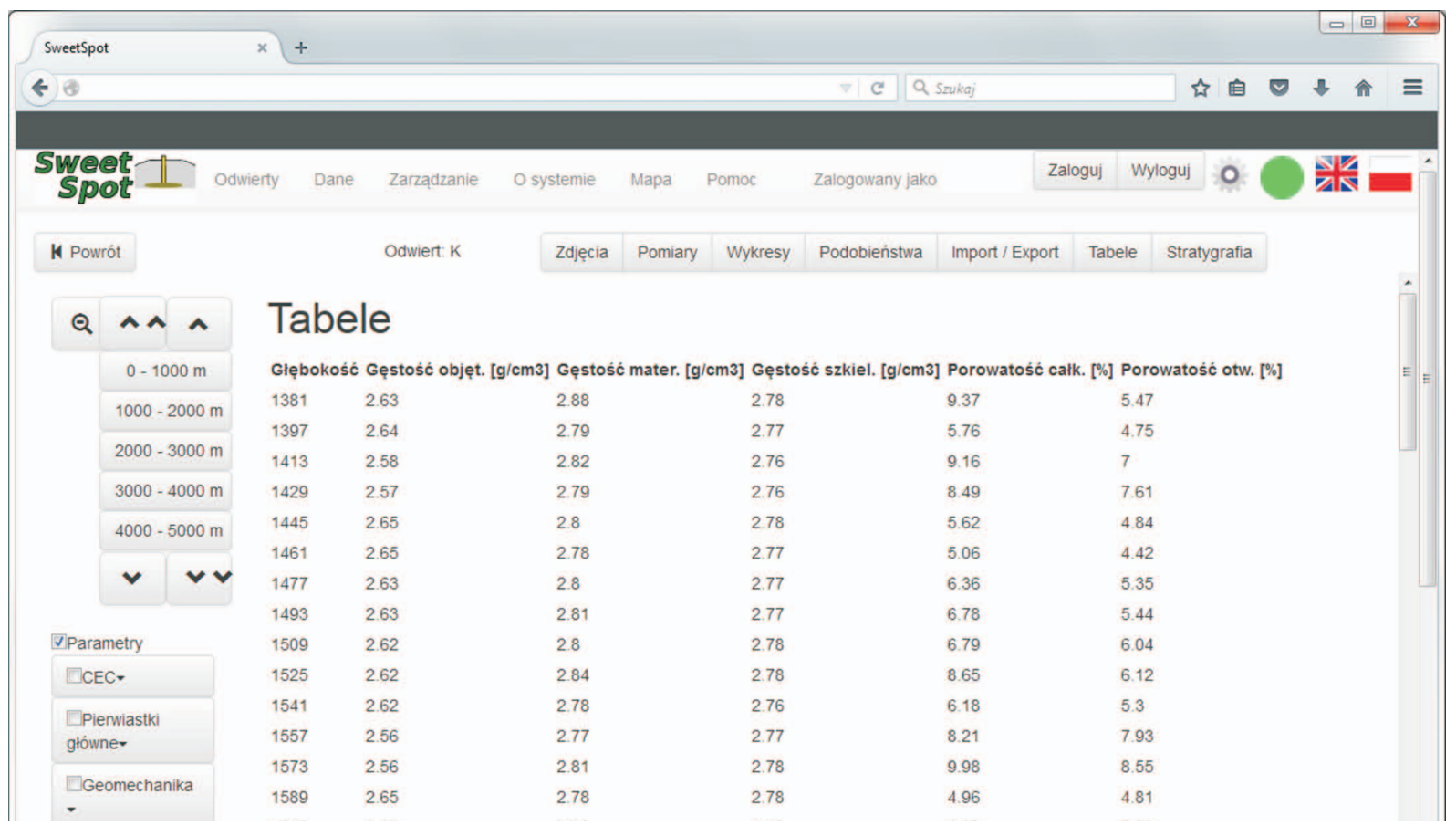

Fig. 11. Presentation of the "filtered" data in a tabular form

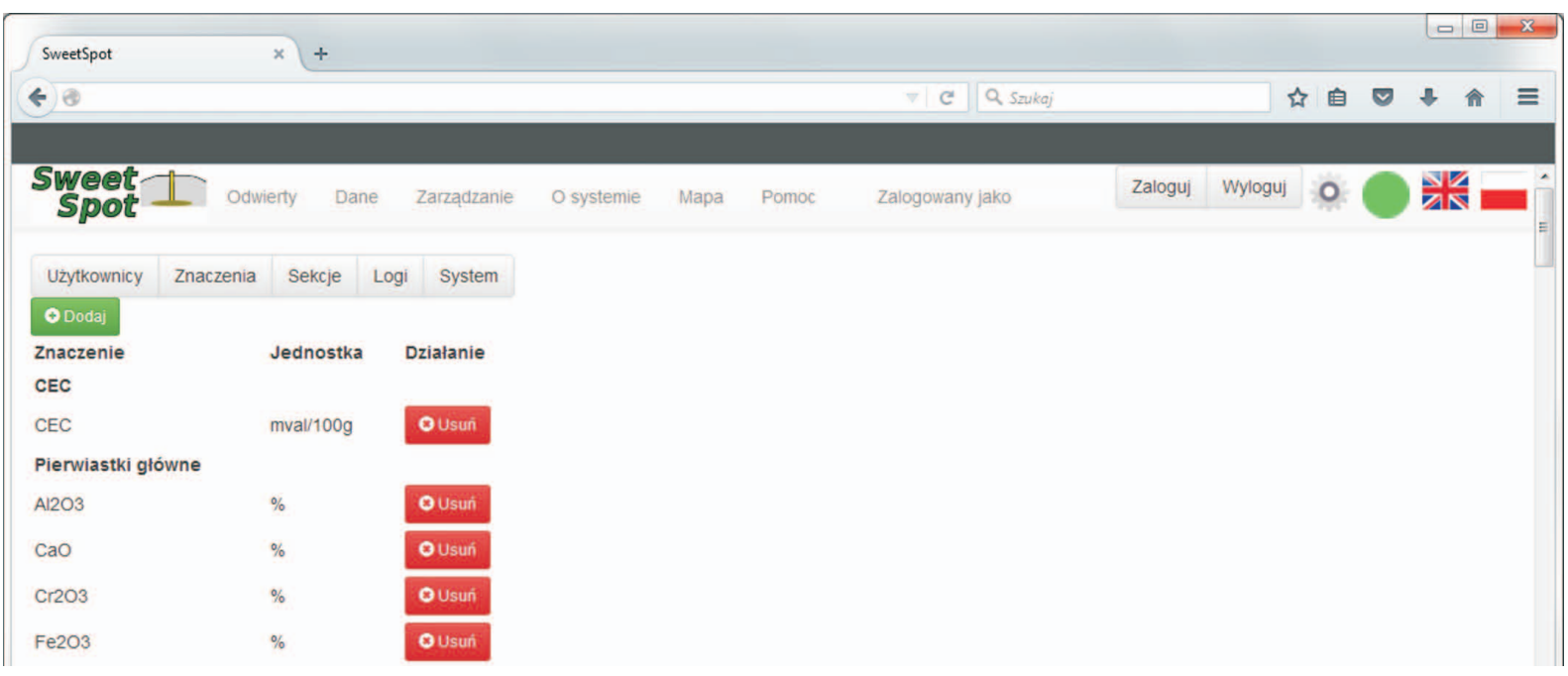

Fig. 12. A page for definitions of the meanings (study results)

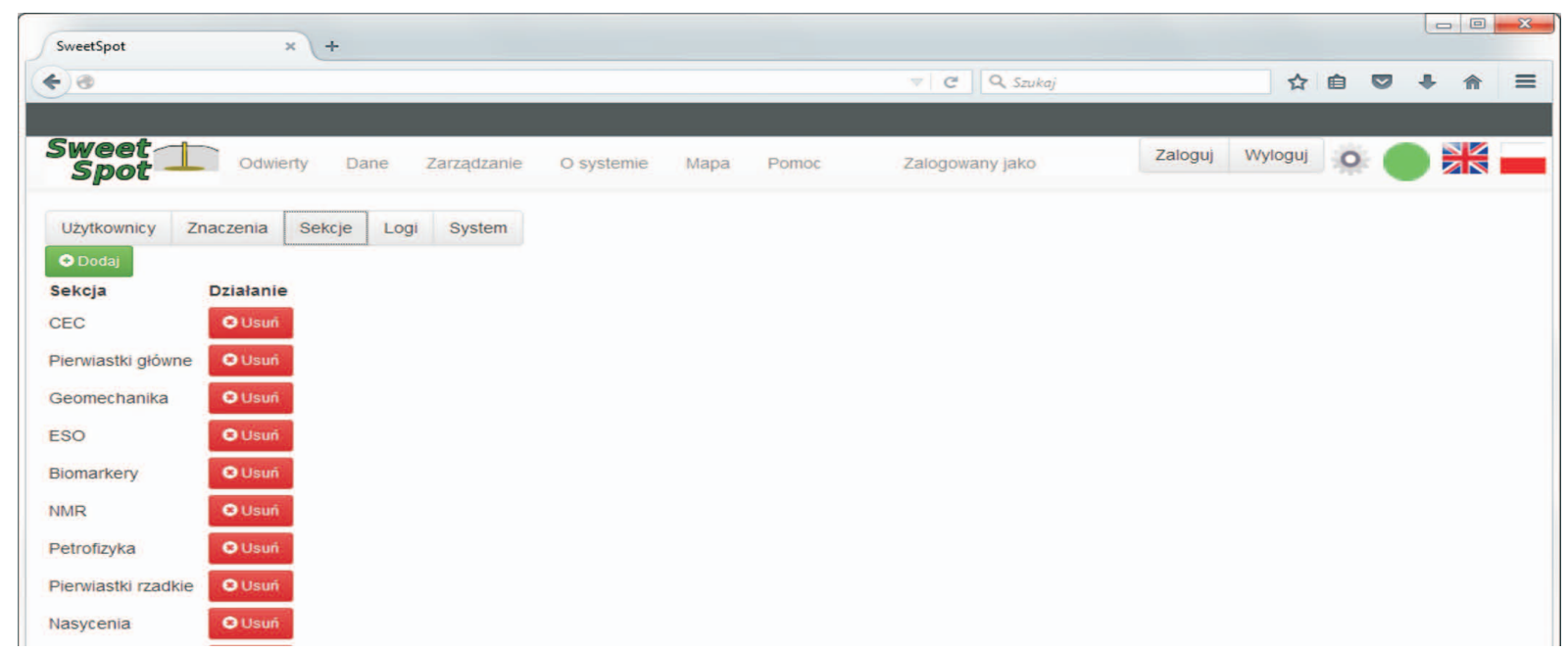

Fig. 13. A page for definitions and edition of the sections 
to visit the repository, for example in order to select the sampling locations for further study,

- better visual determination of the basic parameters of the deposit, due to the ability to magnify the core surface image (e.g. a scale higher than 1:1),

- comparison of geophysical logging data with the collected (and photographed) core,

- use the data for the correlation of deposit horizons (particularly when the number of cores is high),

- sedimentological examinations, etc.

- supporting the process of preparing deposit documentations and design work,
- $\quad$ supporting the decision making process regarding the tasks and operations performed inside the borehole (e.g. controlling the correctness of selection of the perforation interval, collection of correlation of images with geophysical logs),

- quick and easy browsing, processing, transmitting and printing of data, etc.

Although the presented database has been created having in mind its use for the information collected for boreholes drilled in unconventional shale-type deposits, it can be also used for conventional deposits, since from the standpoint of usefulness its contents depend solely on the needs of the user.

Please cite as: Nafta-Gaz 2015, no. 12, pp. 944-952, DOI: 10.18668/NG2015.12.02

Article contributed to the Editor 20.10.2015. Approved for publication 25.11.2015.

The article is the result of research conducted in connection with the project: The methodology for determining sweet spots on the basis of geochemical, petrophysical, geomechanical properties based on the correlation of laboratory test results with geophysical measurements and 3D generating model, co-funded by the National Centre for Research and Development as part of the programme BLUE GAS - POLISH SHALE GAS. Contract No. BG1/MWSSSG/13.

\section{Literature}

[1] Budak P., Falkowicz S.: Zastosowanie cyfrowej fotografii rdzeni wiertniczych $w$ dokumentacji otworowej. Konferencja Naukowo-Techniczna Geopetrol 2004. Prace Instytutu Nafty i Gazu no. 130 , pp. 775-778.

[2] Budak P.: Rzeczpospolita lupkowa. Studium wiedzy o gazie z formacji lupkowych. Rozdziat XIII. Dokumentowanie materialu rdzeniowego. Prace Naukowe Instytutu Nafty i Gazu 2012, no. 183, pp. 297-308.

[3] Dohnalik M., Kowalska S., Mikolajewski Z., Domonik A., Tabor Z.: Sklad mineralny lupkow a wyniki testu trojosiowego sciskania - na przykladzie skal sylurskich $i$ ordowickich z NE Polski. Nafta-Gaz 2015, no. 6, pp. 355-360.

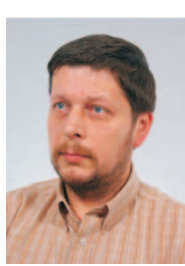

Paweł BUDAK M.Sc. Eng.

Senior Science and Research Specialist

Head of the Department of Petroleum Engineering

Oil and Gas Institute - National Research Institute

ul. Lubicz 25 A

31-503 Kraków

E-mail: pawel.budak@inig.pl

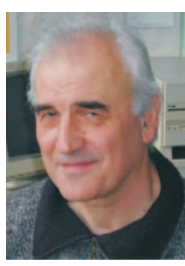

Dr. Eng. Tadeusz SZPUNAR PhD.

Assistant Professor

Department of Petroleum Engineering

Oil and Gas Institute - National Research Institute

ul. Lubicz 25 A

31-503 Kraków

E-mail: tadeusz.szpunar@inig.pl

Eng. Kacper RADZIKOWSKI

Programmer

Warsaw University of Technology

Department of Electronics and Information Technology

ul. Nowowiejska 15/19

00-665 Warszawa

E-mail: radzikowskikacper@gmail.com
[4] Mroczkowska-Szerszen M., Ziemianin K., Brzuszek P., Matyasik I., Jankowski L.: Typ substancji organicznej w lupkach, a jej widma spektroskopowe FTIR-ATR. Nafta-Gaz 2015, no. 6, pp. 361-369.

[5] Nowak R. M.: Polyglot programming the applications to analyze genetic data. BioMed Research International 2014, vol. 2014, pp. 1-7. DOI: 10.1155/2014/253013.

[6] Such P., Lesniak G., Budak P.: Kompleksowa metodyka badania wlasciwosci petrofizycznych skal. Prace Instytutu Nafty i Gazu no. 142, Kraków 2007.

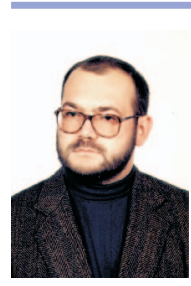

Dr. Eng. Piotr ŁĘTKOWSKI PhD.

Assistant Professor

Department of Hydrocarbon Deposits and UGS

Facilities Simulation

Oil and Gas Institute - National Research Institute

ul. Lubicz 25 A, 31-503 Kraków

E-mail:piotr.letkowski@inig.pl

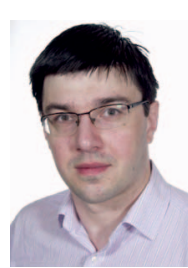

Dr hab. Eng. Robert NOWAK

Lecturer/Assistant Professor

Warsaw University of Technology

Department of Electronics and Information Technology

Institute of Electronic Systems

ul. Nowowiejska 15/19, 000-665 Warszawa

E-mail: R.M.Nowak@elka.pw.edu.pl

Prof. dr hab. Eng. Jarosław ARABAS

Associate Professor

Warsaw University of Technology

Department of Electronics and Information Technology

Institute of Electronic Systems

ul. Nowowiejska 15/19, 00-665 Warszawa

E-mail: jarabas@ise.pw.edu.pl 